\title{
A computational tool for hydrosedimentological and statistical calculations
}

\author{
Ferramenta computacional para cálculos hidrossedimentológicos e estatísticos
Bruno Bernardo dos Santos ${ }^{1,2 *} \odot$, Frederico Fábio Mauad' ${ }^{\oplus}$, Renato Billia de Miranda' ${ }^{\oplus}$, Teodorico Alves Sobrinho² ${ }^{\circledR}$, Paulo Tarso Sanches de Oliveira ${ }^{2}$ (])

\begin{abstract}
This paper presents a new computational tool called NH SEDIMENT AND STATISTIC which performs hydrosedimentological and statistical calculations using Visual Basic. This computational tool was developed for studies related to calculations of sediment transport in rivers. The tool includes hydrosedimentological methods for calculating suspension loads, bed loads, and total solid discharge. In addition, it provides the user with the possibility of performing statistical tests such as the Kolmogorov-Smirnov normality test, $F$ test and $\chi^{2}$ test of variance, Student's $t$-test, non-parametric Wilcoxon test, and statistical parameter calculations. The NH SEDIMENT AND STATISTIC automatically calculates and provides the main results for each of the methods, allowing the user to draw their own conclusions. This proposed computational tool supports hydrosedimentological studies, and is reliable and easy to use, contributing to the reduction of sediment-related problems in the areas of hydraulic engineering, geology, and soil and water conservation. Furthermore, this tool may be used in transdisciplinary scientific areas for complete planning and management of water resources.
\end{abstract}

Keywords: sedimentology; sediment-transport; statistic; software

\begin{abstract}
RESUMO
Este artigo apresenta uma nova ferramenta computacional chamada $\mathrm{NH}$ SEDIMENT AND STATISTIC, que realiza cálculos hidrossedimentológicos e estatísticos usando o Visual Basic. Essa ferramenta computacional foi desenvolvida para estudos relacionados a cálculos de transporte de sedimentos em rios. A ferramenta inclui métodos hidrossedimentológicos para calcular cargas de suspensão, cargas de leito e descarga total de sólidos. Além disso fornece ao usuário a possibilidade de realizar testes estatísticos, como o teste de normalidade Kolmogorov-Smirnov, teste $F$ e teste de variância do $\chi^{2}$, teste T de Student, testenão paramétrico de Wilcoxon e cálculos estatísticos de parâmetros. O NH SEDIMENT AND STATISTIC calcula e fornece automaticamente os principais resultados para cada um dos métodos, permitindo que o usuário tire suas próprias conclusões. Essa ferramenta computacional proposta suporta estudos hidrossedimentológicos e é confiável e fácil de usar, contribuindo para a redução de problemas relacionados a sedimentos nas áreas de engenharia hidráulica, geologia, conservação de solo e água. Além disso, essa ferramenta pode ser usada em áreas científicas transdisciplinares para um planejamento e gerenciamento completos dos recursos hídricos.
\end{abstract}

Palavras-chave: sedimentologia; transporte de sedimentos; estatística; software

\section{INTRODUCTION}

There has been a growing demand for knowledge on processes related to sediment dynamics in water resources in recent decades due to their significance to many issues, such as siltation and transport of sediment-bound pollutants (OEURNG; SAUVAGE; SÁNCHEZ-PÉREZ, 2010; SUN et al., 2016). Therefore, sediment dynamics have been studied and the possible interactions of these particles in the environment are current topics in different scientific areas, such as hydraulic engineering, geology, soil and water conservation, and water resources planning.

The study of hydrosedimentological processes involves the determination of suspended load (Qss), bed load (Qsa), and total solid discharge (Qst), however it is difficult to obtain due to the numerous variables involved. According to Vercruysse, Grabowski and Rickson (2017), despite decades of research, the factors and process interactions underlying sediment transport in rivers have not yet been fully captured and understood.

Sedimentometry involves measuring water discharge, suspended and bed material, water temperature, energy line slope, among others (GRAY; LANDERS, 2014). Suspended sediment concentration is a fundamental parameter in determining deposition rates and sediment flow, and estimating them accurately is essential for understanding their behavior in the water column and solid discharge prediction (GARTNER, 2004; XAVIER et al., 2014). For this reason, several approaches and methods have been developed for sediment discharge

$\square$

'Escola de Engenharia de São Carlos, Universidade de São Paulo - São Carlos (SP), Brazil.

2Faculdade de Engenharia, Arquitetura, Urbanismo e Geografia, Universidade Federal do Mato Grosso do Sul - Campo Grande (MS), Brazil.

*Corresponding author: bbernardo49@gmail.com

Conflicts of interest: The authors declare no conflict of interest.

Funding: Brazilian Electricity Regulatory Agency (ANEEL) and AES Tietê S.A. grant number ANEEL PD-0064-1028/2011, and National Council for Scientific and Technological

Development (CNPq)-grants 142305/2015-4 and 371374/2019-7.

Received: 03/17/2O2O - Accepted: 06/12/2O2O - Reg. ABES: 20200093 
(ALONSO; NEIBLING; FOSTER, 1981; STEVENS; YANG, 1989; SCAPIN; PAIVA; BELING, 2007; GRAY; SIMÕES, 2008; VERCRUYSSE; GRABOWSKI; RICKSON, 2017). Nagy, Watanabe and Hirano (2002), for example, used artificial neural networks (ANN) to estimate the solid discharge in rivers. However, the most traditional indirect measurement is made by collecting samples, either in suspension or bed material, determining the watercourse characteristics and particle size analysis of the sediment, enabling the calculation of $\mathrm{Q}_{\mathrm{SA}}$ and $\mathrm{Q}_{\mathrm{ST}}$ using different methods and formulas (ALONSO; NEIBLING; FOSTER, 1981; GRAY; SIMÕES, 2008; SANTOS et al., 2012).

Methods for $\mathrm{Q}_{\mathrm{ST}}$ calculation, such as the Colby's method (COLBY, 1957) and others, require abacus analysis, which make the calculation subjective, varying according to personal interpretation. Computational tools in these situations are essential, as they assist hydrosedimentological calculations, reducing systemic errors from these interpretations. WinTSR (ROSA; BELING, 2002), Colby_W (CARVALHO, 2008), and SEDIM 2.0 (CAMPEÃO; HORA, 2019) are examples of software that help achieve solid discharge. However, they have limitations such as the fact that they are incompatible in some recent systems, need data that is not required for some methods, and require unitary calculations which are time-consuming in situations where there are many sections. Therefore, there is a lack of adequate and easy-to-use tools for studying sediment transport-related processes.

Moreover, sediment monitoring is crucial for understanding hydrosedimentological processes, requiring the amount of data that necessarily needs statistical calculations and using a computer as a work tool. Thus, due to the few options of free and open access statistical software such as R (THE R FOUNDATION, 2019), we developed an easy-to-use publicly available computational tool that integrates statistical and hydrosedimentological calculations. It is worth mentioning that $\mathrm{R}$ is a software that requires minimal knowledge of the $\mathrm{R}$ language, as well as downloading packages to perform statistical tests.

In this paper, the aim was to introduce a Visual Basic for Applications (VBA) computational tool called NH SEDIMENT AND STATISTIC, which provides a free, easy-to-use, and efficient solution for hydrosedimentological and statistical calculations. It provides the possibility to calculate suspended loads, bed loads, and total loads and performs important statistical tests, such as the Kolmogorov-Smirnov normality test, Fisher-Snedecor, and Student's $t$ parametric tests, Wilcoxon non-parametric test, and statistical parameter calculations. The tool also enables agility in the calculations, as it has distinct modules that allow the user, who has little statistical domain, to apply their results obtained in the hydrosedimentological module directly in the statistical module without needing to purchase or acquire other software.

\section{OVERVIEW OF THE NH SEDIMENT AND STATISTIC}

\section{General considerations}

NH SEDIMENT AND STATISTIC (NHSS) is a computational tool developed for engineers and professionals involved in projects related to sediment transport in water resources, which allows the user to perform hydrosedimentological and statistical calculations (Figure 1). The computer routine has been written in Visual Basic for Applications. We opted for this kind of language for its richness and flexibility in functionality, and especially as it is easy to access, user-friendly and has an intuitive user interface, including an interactive component with databases.

The interface of the computational tool was divided into two different modules: hydrosedimentological and statistical. This makes the application objective and organized with smaller program coding and better understanding, which favors script changes and saves computational memory on calculations.

The hydrosedimentological module was developed for calculating suspended loads (Qss), bed loads (Qsa), and total solid discharge (Qst) required for various sedimentological studies. The implementation of these methods is related to time optimization since the tool allows Qss, Qsa, and Qst calculations of multiple sections in one step, while in other software, obtaining these parameters is unitary from section to section. Moreover, unlike hydrosedimentology software, the computational tool developed is a multidisciplinary software that also performs statistical calculations.

The statistical module is recommended for applications of the KolmogorovSmirnov's test for normality, variance test, mean test, nonparametric median test, and calculation of statistical parameters. It is possible to use the statistical module in other types of data such as hydrological, rainfall, fluviometric, and even information from other areas that require statistical analysis, confirming the multidisciplinarity of the tool.

The user license is free, and the script, manuals, and guides are available on the website for this paper acknowledging the implementation of other methods as needed and changes to the existing ones. The use of the computational tool NHSS does not require prior knowledge of computational language and allows the user to work with statistical tests and methods of hydrosedimentological calculations, which is unique in this case.

\section{Hydrosedimentological module of NHSS}

The hydrosedimentological module of the NHSS computational tool allows the user to choose the appropriate solid discharge calculation method according to the data they have and their objectives. The calculation of suspended solid discharge is based on the method presented by National Water Agency (ANA, 2012). Having data of water discharge $\left(\mathrm{m}^{3} \cdot \mathrm{s}^{-1}\right)$ and suspended solids concentration (mg. $\mathrm{L}^{-1}$ or ppm), Qss is calculated through Equation 1 which synthesizes the conservation of sediment mass up to a certain moment.

Qss $=0.00864 \times \mathrm{Q} \times \mathrm{SSC}$

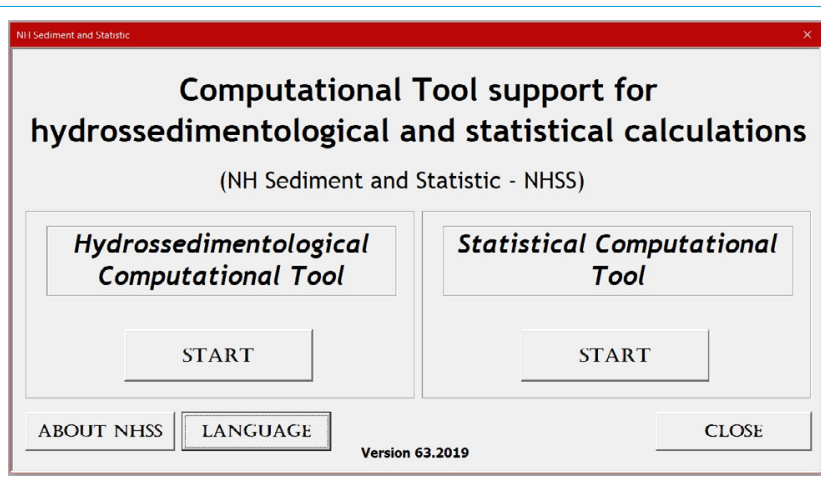

Source: elaborated by the authors.

Figure 1 - Main screen of NH SEDIMENT AND STATISTIC (NHSS) 
Where:

Qss = suspended load or suspended solid discharge [t.day $\left.{ }^{-1}\right]$;

$\mathrm{Q}=$ water discharge $\left[\mathrm{m}^{3} \cdot \mathrm{s}^{-1}\right]$;

SSC $=$ suspended solid concentration $\left[\mathrm{mg} \cdot \mathrm{L}^{-1}\right]$.

Regarding the bed load, the codification of the Meyer-Peter and Muller (1948), which considers the solid load in permanent contact with the riverbed, was based on Equations 2 to 5 .

$\gamma \cdot \frac{\mathrm{Q}_{\mathrm{s}}}{\mathrm{Q}}\left(\frac{\mathrm{K}_{\mathrm{s}}}{\mathrm{K}_{\mathrm{r}}}\right)^{3 / 2} \cdot \mathrm{p} \cdot \mathrm{S}=0.047 \cdot \gamma_{\mathrm{s}}^{\prime} \cdot \mathrm{D}_{\mathrm{m}}+0.25 \cdot\left(\frac{\gamma}{\mathrm{g}}\right)^{1 / 3} \cdot \mathrm{q}_{\mathrm{sa}}^{2 / 3}$

$\mathrm{K}_{\mathrm{s}}=\frac{1}{\mathrm{n}_{\mathrm{s}}}$

$\mathrm{K}_{\mathrm{r}}=\frac{26}{\left(\mathrm{D}_{90}\right)^{1 / 6}}$

$$
\gamma_{\mathrm{S}}^{\prime}=\gamma_{\mathrm{S}}-1
$$

\section{Where:}

$\gamma=$ Specific weight of water $\left[\mathrm{t}_{\mathrm{m}} \mathrm{m}^{-3}\right]$;

$\mathrm{Qs}=$ part of water discharge influencing the bed river $\left[\mathrm{m}^{3} . \mathrm{s}^{-1}\right]$;

$\mathrm{Q}=$ total water discharge $\left[\mathrm{m}^{3} \cdot \mathrm{s}^{-1}\right]$;

Ks $=$ Strickler's roughness coefficient;

$\mathrm{n}_{\mathrm{s}}=$ Manning's roughness coefficient;

$\mathrm{Kr}=$ particle roughness coefficient;

$\mathrm{D}_{90}=$ diameter of the particle in which $90 \%$ of a sample's mass is smaller [m];

$\mathrm{p}=$ mean depth $[\mathrm{m}]$;

$\mathrm{S}=$ energy line $\left[\mathrm{m} \cdot \mathrm{m}^{-1}\right]$;

$\gamma_{\mathrm{s}}=$ specific weight of submerged sediment $\left[\mathrm{t} \cdot \mathrm{m}^{-3}\right]$;

$\gamma_{\mathrm{s}}=$ specific weight of sediment $\left[\mathrm{t} \cdot \mathrm{m}^{-3}\right]$;

$\mathrm{D}_{\mathrm{m}}=$ mean diameter of particles $[\mathrm{m}]$;

$\mathrm{g}=$ gravitational acceleration $\left[\mathrm{m} \cdot \mathrm{s}^{-2}\right]$;

$\mathrm{q}_{\mathrm{sa}}=$ bed load per unit width $\left[\mathrm{t} \cdot \mathrm{s}^{-1} \mathrm{~m}^{-1}\right]$.

Due to the amount of data required, some of which were difficult to obtain, we prioritized facilitating the estimation of the Qsa. Then, we implemented an area for calculation of the mean particle diameter (Equation 6) in this bed load module. In addition, we allowed the user to choose the form of calculation: with known or unknown energy gradient (S), where in this second option, $\mathrm{S}$ is calculated by the Manning formula (Equation 7).

$\mathrm{D}_{\mathrm{m}}=\sum \mathrm{D}_{\mathrm{si}} \mathrm{i}_{\mathrm{f}}$

Where:

$\mathrm{D}_{\mathrm{m}}=$ mean diameter of particles;

$\mathrm{D}_{\mathrm{si}}=$ geometric mean diameter between two diameters of a particle size range; $\mathrm{i}_{\mathrm{f}}=$ particle size fraction between the two diameters, usually presented in $\%$.

$\mathrm{S}=\left(\frac{\mathrm{Q} \cdot \mathrm{n}_{\mathrm{S}}}{\mathrm{A} \cdot \mathrm{R}^{2 / 3}}\right)^{2}$
Where:

$\mathrm{S}=$ energy line $\left[\mathrm{m} \cdot \mathrm{m}^{-1}\right]$;

$\mathrm{Q}=$ water discharge $\left[\mathrm{m}^{3} \cdot \mathrm{s}^{-1}\right]$;

$\mathrm{A}=$ section area $\left[\mathrm{m}^{2}\right]$;

$\mathrm{R}=$ hydraulic radius $[\mathrm{m}]$;

$\mathrm{n}_{\mathrm{s}}=$ Manning's roughness coefficient.

The NHSS computational tool also allows the calculation of total solid discharge by the simplified Colby (1957) method (Equation 8).

Qst $=$ Qsm + Qnm

Where:

Qst $=$ total solid discharge or total load $\left[\mathrm{t}^{\mathrm{day}}{ }^{-1}\right]$;

Qsm $=$ measured solid discharge $\left[\mathrm{t}^{- \text {day }^{-1}}\right]$;

Qnm $=$ unmeasured Solid Discharge $\left[\mathrm{t}_{\text {day }}{ }^{-1}\right]$.

The measured solid discharge (Qsm) can be obtained by calculating the suspended solid discharge (Equation 1) while the unmeasured solid discharge (Qnm), which represents an integration of bed load with the unmeasured solid discharge, is estimated with the aid of an abacus (Supplementary Figures S1 and S2 - http://abes-dn.org.br/wp-content/ uploads/2021/04/SupplementaryFIle_atualizado.pdf) from velocity $\left(\mathrm{m} . \mathrm{s}^{-1}\right)$, mean depth $(\mathrm{m})$, concentration $\left(\mathrm{mg} \cdot \mathrm{L}^{-1}\right)$, and section width $(\mathrm{m})$ data (Equation 9).

$\mathrm{Q}_{\mathrm{nm}}=\mathrm{q}_{\mathrm{nm}}^{\prime} \cdot \mathrm{k} \cdot \mathrm{L}$

Where:

$\mathrm{q}_{\mathrm{nm}}^{\prime}=$ unmeasured solid discharge per meter of width $\left[\mathrm{t}_{\text {.day }}{ }^{-1} \cdot \mathrm{m}^{-1}\right]$;

$\mathrm{L}=$ width of sampled section $[\mathrm{m}]$;

$\mathrm{k}=$ correction factor [adimensional].

Representative equations for Abacus 1 to 3 were obtained using Engauge Digitizer software, developed by Mitchell (2019), which recovers chart data points automatically, so as to obtain equations that could be encoded in VBA language (Equations 10 to 12). This tool is used in various areas of knowledge, such as mathematics and chemistry (BEN-TAL; SHAMAILOV; PATON, 2014; OCAYA, 2014; DOUZIECH et al., 2018).

$\log q_{n m}^{\prime}=3.340 \cdot \log V+1.617$

$\log \mathrm{Cr}=\mathrm{A} \cdot \log \mathrm{V}+\mathrm{B}$

$\log \mathrm{k}=0.4819 \cdot \log \mathrm{Re}+0.0739$,

Where:

$\mathrm{Cr}=$ Relative suspended sediment concentration $\left[\mathrm{mg} . \mathrm{L}^{-1}\right]$;

$\mathrm{A}$ and $\mathrm{B}=$ linear and angular coefficients that vary as a function of depth (Supplementary Table S1);

$\mathrm{Re}=$ availability ratio;

$\mathrm{k}=$ correction factor. 


\section{Statistical module of NHSS}

The user has an option to perform the Kolmogorov-Smirnov test for normality, test of variances $\left(\chi^{2}\right.$ test or F-test), means tests (one-sample, independent samples with equal or different variances, or paired Student's $t$-test), and Wilcoxon nonparametric test for median. VBA has ready algorithms for calculations involving the means and variance tests that can be accessed directly in the programming code. However, the Kolmogorov-Smirnov and Wilcoxon tests do not have reliable equations available in the VBA. Then, the respective equations and approximations used in the normality test are in agreement with Lilliefors (1967), Stephens (1974), and Dallal and Wilkinson (1986). For the Wilcoxon test, we used equations presented by Wilcoxon (1945), Mann and Whitney (1947) and Conover (1999). We emphasize that the respective main equations and approximations for these tests implemented at NHSS can be checked in Supplementary Tables S2 and S3 (http:// abes-dn.org.br/wp-content/uploads/2021/04/SupplementaryFIle_atualizado.pdf).

In this module, statistical parameters were also implemented for model efficiency evaluation and data comparison. We chose to enter NHSS equations for calculations of Adjustment coefficient (AC) (Equation 13), Efficiency (EF) (Equation 14), Coefficient of Residual Mass (CRM) (Equation 15), Root Mean Square Error (RMSE) (Equation 16), Maximum Error (ME) (Equation 17), and Mean Difference (MD) (Equation 18), which can be used in various studies as validations of models of soil nutrient dynamics, comparative analysis of different methods of obtaining variables, comparison of different models of estimation of infiltration rates or methods of solid sediment discharge, among others (LENGNICK; FOX, 1994; SENTELHAS et al., 1997; ALVES SOBRINHO et al., 2003; BRITO et al., 2009; SANTOS et al., 2012; BIELENKI JUNIOR et al., 2018; MARQUES et al., 2019).

$$
\begin{aligned}
& \mathrm{AC}=\frac{\sum_{\mathrm{i}=1}^{\mathrm{n}}\left(\mathrm{O}_{\mathrm{i}}-\overline{\mathrm{O}}\right)^{2}}{\sum_{\mathrm{i}=1}^{\mathrm{n}}\left(\mathrm{P}_{\mathrm{i}}-\overline{\mathrm{O}}\right)^{2}} \\
& \mathrm{EF}=\frac{\sum_{\mathrm{i}=1}^{\mathrm{n}}\left(\mathrm{O}_{\mathrm{i}}-\overline{\mathrm{O}}\right)^{2}-\sum_{\mathrm{i}=1}^{\mathrm{n}}\left(\mathrm{O}_{\mathrm{i}}-\mathrm{P}_{\mathrm{i}}\right)^{2}}{\sum_{\mathrm{i}=1}^{\mathrm{n}}\left(\mathrm{O}_{\mathrm{i}}-\overline{\mathrm{O}}\right)^{2}} \\
& \mathrm{CRM}=\frac{\left[\sum_{\mathrm{i}=1}^{\mathrm{n}}\left(\mathrm{O}_{\mathrm{i}}\right)-\sum_{\mathrm{i}=1}^{\mathrm{n}}\left(\mathrm{P}_{\mathrm{i}}\right)\right]}{\sum_{\mathrm{i}=1}^{\mathrm{n}}\left(\mathrm{O}_{\mathrm{i}}\right)} \\
& \mathrm{RMSE}=\sqrt{\frac{\sum_{\left(\mathrm{O}_{\mathrm{i}}-\mathrm{P}_{\mathrm{i}}\right)^{2}}^{\mathrm{n}}}{\mathrm{ME}}=\max \left|\mathrm{O}_{\mathrm{i}}-\mathrm{P}_{\mathrm{i}}\right|} \\
& \mathrm{MD}=\frac{\sum_{\mathrm{i}=1}^{\mathrm{n}}\left(\mathrm{O}_{\mathrm{i}}-\mathrm{P}_{\mathrm{i}}\right)}{\mathrm{n}}
\end{aligned}
$$

Where:

$\mathrm{i}=$ index of $\mathrm{O}$;

$\mathrm{Oi}=$ observed value;

$\mathrm{Pi}$ = estimated value;

$\overline{\mathrm{O}}=$ mean of the observed values;

$\mathrm{n}=$ sample size

\section{CASE STUDY AND NHSS COMPUTATIONAL TOOL VERIFICATION}

The computational tool NHSS was tested on the reservoir of the Mogi-Guaçu Small Hydroelectric Power Plant (SHP) (22 $22^{\prime} 45.6^{\prime \prime}$ S; 46 $53^{\prime} 59.1^{\prime \prime} \mathrm{W}$ ) and
Guariroba basin, located between the parallels $20^{\circ} 28^{\prime}$ and $20^{\circ} 43^{\prime} \mathrm{S}$, and the meridians $54^{\circ} 11^{\prime}$ and $54^{\circ} 11^{\prime} \mathrm{W}$.

Mogi-Guaçu SHP is a $7.2 \mathrm{MW}$ installed potency and $5.73 \mathrm{~km}^{2}$ reservoir located between the municipalities of Mogi-Guaçu and Mogi-Mirim (São Paulo, Brazil). Originally designed for flood control and hydropower generation purposes, the reservoir also serves as the main water supply for two nearby cities (ESTIGONI; MIRANDA; MAUAD, 2017). Soils are mainly Latosols and major land uses are agriculture, forest, pasture, and silviculture $(62.8,15.3,10.9$, and $5.4 \%$, respectively). The climate is Cwa according to Köppen, humid, warm in the summer and temperate in the winter, with an average annual rainfall of approximately 1,300 mm year ${ }^{-1}$ (Environmental Company of the State of São Paulo - CETESB, 2017). Further information about Mogi-Guaçu SHP and Mogi-Guaçu basin can be found in Estigoni, Miranda and Mauad (2017), Foundation for Research Increase and Industrial Improvement (FIPAI, 2015), Mogi Guaçu River Basin Committee (CBH MOGI, 2018) and Santos et al. (2019).

We measured hydraulic characteristics, suspended concentration of sediments, turbidity and temperature in two campaigns in 2014 along the reservoir. The hydraulic characteristics obtained through Acoustic Doppler Current Profiler (ADCP) (Model M9, Sontek) provide the hydraulic data of width, depth, total section area, velocity, water discharge, among other information. Moreover, the LISST-100X (Sequoia Scientific, Inc.) and multiparameter YSI 6,600 probe (YSI Inc.) mounted in a protective cage was lowered through a water column measuring volumetric suspended concentration of sediments $\left(\mu \mathrm{L} . \mathrm{L}^{-1}\right)$, turbidity (NTU), and water temperature $\left({ }^{\circ} \mathrm{C}\right)$. Simultaneously, watersediment samples were collected at the surface approximately $1 \mathrm{~m}$ deep and close to the bottom using a Van Dorn bottle to compare with those obtained with the other equipment. These samples were then sent to the laboratory where the gravimetric concentration of suspended sediments was determined by the gravimetric method following the procedures proposed by the Standard methods for examination of water and wastewater of the American Public Health Association (APHA, 1995). All data measured and used in this paper are available in Supplementary Tables S4 to S10 (http://abes-dn.org.br/wp-content/ uploads/2021/04/SupplementaryFIle_atualizado.pdf).

The other case study area was the Guariroba River Basin, which has 36,200 ha and is located in the rural side of Campo Grande, Mato Grosso do Sul State, Brazil. This watershed is the main water supply, as it provides about $50 \%$ of the total water consumed by the urban area of Campo Grande, Mato Grosso do Sul, Midwestern Brazil (SONE et al., 2019). According to Köppen, the climate is Aw, described as Brazilian Cerrado and characterized by a low temperature of $18^{\circ} \mathrm{C}$. The wet season starts in October and ends in May while the dry season runs from June to September. Further information about the Guariroba river basin can be found in Colman et al. (2018), Almagro et al. (2019), Sone et al. (2019). In this case, we measured hydraulic data and the bed sediment particle size between 2017 and 2019 of three sections of the Guariroba river with distinct characteristics using ADCP (Riversurveyor Model M9, Sontek) and BLM-84 sampler for bed loads, among others (Supplementary Table S11 - http://abesdn.org.br/wp-content/uploads/2021/04/SupplementaryFIle_atualizado.pdf).

All data obtained were applied in the NHSS and we compared the results obtained in the hydrosedimentological module from the proposed tool with WinTSR software (ROSA; BELING, 2002) and SEDIM 2.0 (CAMPEÃO; HORA, 2019). Furthermore, the results obtained from the statistical module of the computational tool were compared with the results provided by the R environment. 


\section{Simulations in the computational tool: Hydrosedimentological Module}

The calculation of suspended load (Qss) and total load by the simplified Colby's method using the computational tool developed was done for some sections of the Mogi-Guaçu reservoir. This is illustrated, respectively, in Figures 2 and 3. However, the bed load calculation using the Meyer-Peter and Muller method was performed with observed data from the Guariroba basin where the bed sediment transport is more significant than a reservoir (Figure 4). In all cases, the solid discharge calculations provided by the NHSS computational tool were consistent.

The NHSS was used in the evaluation because it allows the calculations of statistical parameters used in the most method comparisons. For the bed load (Figure 5A) and total solid discharge (Figure 5B), the values of the statistical parameters were satisfactory, mainly efficiency (EF close to 1 ) and coefficient of residual mass (CRM close to 0 ). We emphasize that the solid discharge results obtained with the pieces of software, WinTSR and SEDIM 2.0, can be found in Supplementary Table S12 and S13 (http://abes-dn.org.br/wp-content/ uploads/2021/04/SupplementaryFIle_atualizado.pdf).

Our results indicate that the NHSS tool presents total and bed load values similar to the results computed by using WinTSR and SEDIM. Although the main equations involving sediment transport calculation methods are the same, there are slight variations between the pieces of software. Some factors can be listed, such as: different approximations for the equations obtained in the total load calculation abacus, and even different approximations for calculating variables, such as the energy line or Manning's coefficient for calculating the bed load. However, we strive for the developed computational tool better approximations in all cases, which do not affect the interpretation of the results. We also remember that the NHSS optimizes time by calculating such parameters for multiple sections with a single command, while WinTSR and SEDIM require data entry to calculate solid discharge in one section at a time.

\section{Simulations in the computational tool: statistical module}

All simulations involving the NHSS statistical module were performed based on measured suspended sediment concentration data (SSC), estimated concentration of turbidity data (SSC C1), estimated concentration of volumetric data provided by LISST-100X (SSC C2), and water temperature in the Mogi-Guaçu reservoir. Then, it was possible to perform several normality tests (Figure 6), variance tests (Figure 7), the mean comparison test (Figure 8), and the nonparametric median comparison test (Figure 9), emphasizing that the data were previously organized and adjusted to apply the statistical tests correctly.

The accuracy of the statistical results and p-values of the tests was performed by comparing it with the results provided by the R environment using statistical parameters. All results obtained by both programs can be viewed in Supplementary Tables S14 to S17(http://abes-dn.org.br/wp-content/ uploads/2021/04/SupplementaryFIle_atualizado.pdf). We found that, in general, the statistical tests of the developed computational tool presented adequate and similar results to those presented by the software $\mathrm{R}$ (Table 1), mainly because they presented low CRM and RMSE, and AC and EF close to 1.

Although the statistical tests are the same between the R and NHSS computational tools and, in theory, have the same equations, the algorithms are different. This small variation was expected mainly for the calculation of $\mathrm{p}$-value in the Kolmogorov-Smirnov test and in the Wilcoxon statistics calculation where we worked with analytical methods of approximation. In relation to the F-Fisher and the T-Student tests, despite the minimal difference, the ME between the $p$-values obtained was not greater than 0.0038 for the $F$ test and 0.007 for the $t$-test. Therefore, even for a statistical study adopting the significance level of 0.01 , there would be no problems with false conclusions in the tests.

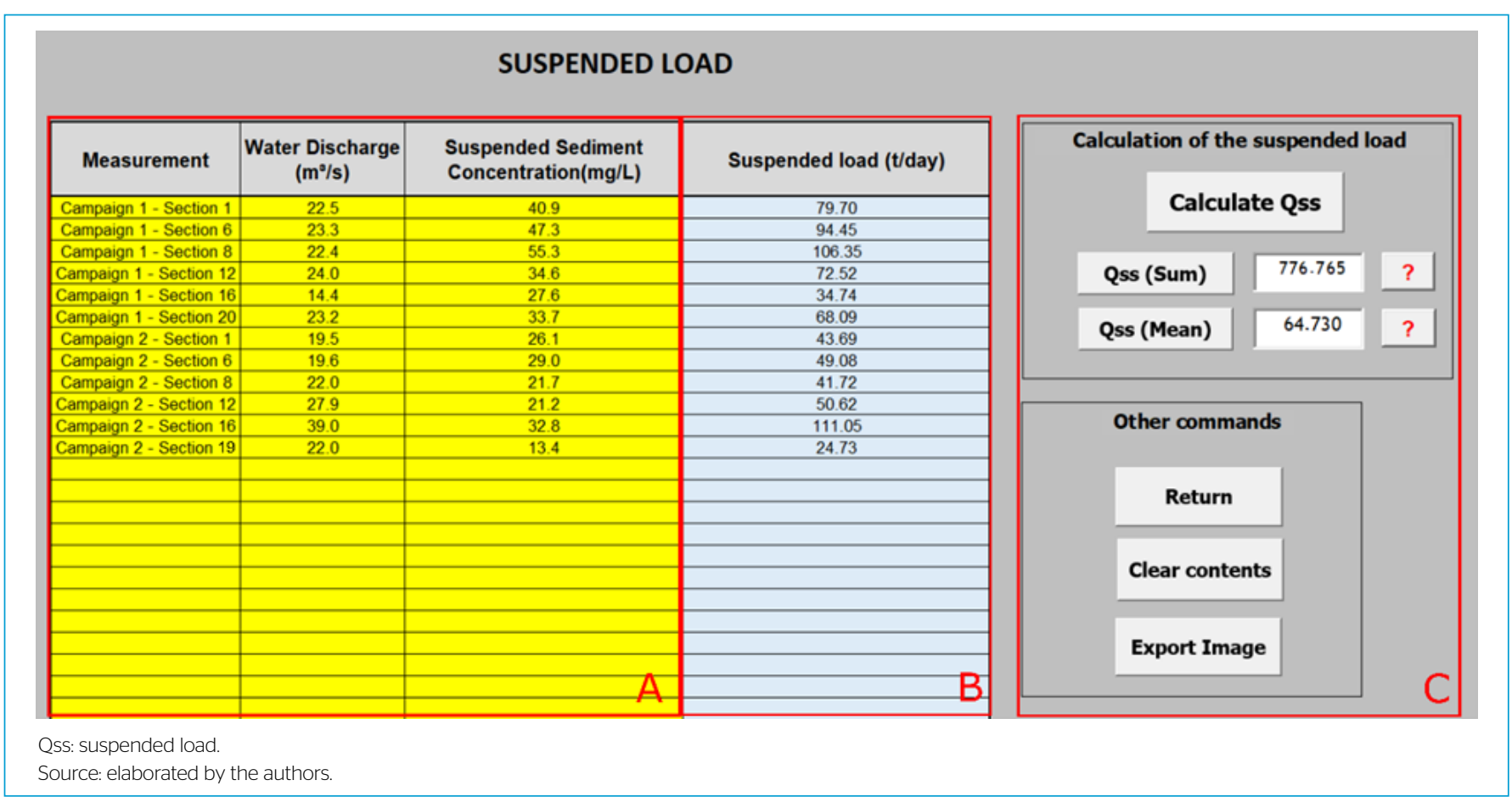

Figure 2 - Suspended load calculation screen on NH SEDIMENT AND STATISTIC: (A) input data area for suspended load calculation; (B) output data area of suspended load; (C) panel control area. 


\begin{tabular}{|c|c|c|c|c|c|c|c|c|c|c|}
\hline \multirow[b]{2}{*}{$\mathrm{n}$} & \multicolumn{9}{|c|}{$\begin{array}{l}\text { Total Solid Discharge } \\
\text { Colby's Simplified Method - Colby (1957) }\end{array}$} & \multirow[b]{2}{*}{$\begin{array}{c}\text { Commands } \\
\text { Calculate (Qst) }\end{array}$} \\
\hline & Measurement & $\begin{array}{c}\text { Water } \\
\text { Discharge } \\
\left(\mathrm{m}^{3} / \mathrm{s}\right)\end{array}$ & $\begin{array}{l}\text { Mean } \\
\text { Velocity } \\
(\mathrm{m} / \mathrm{s})\end{array}$ & $\begin{array}{l}\text { Width } \\
\text { (m) }\end{array}$ & Depth (m) & $\begin{array}{c}\text { Suspended } \\
\text { Sediment } \\
\text { Concentration } \\
(\mathrm{mg} / \mathrm{L})\end{array}$ & $\begin{array}{c}\text { Measured Solid } \\
\text { Discharge - Qss } \\
\text { (t/day) }\end{array}$ & $\begin{array}{c}\text { Unmeasured } \\
\text { Solid Discharge - } \\
\text { Qnm ( } t / \text { day) }\end{array}$ & $\begin{array}{l}\text { Total Solid } \\
\text { Discharge - Qst } \\
\text { (t/day) }\end{array}$ & \\
\hline 1 & C1-S1-1 & 24.22 & 0.064 & 61.29 & 6.450 & 40.855 & 85.493 & 3.012 & 88.504 & Export Imaae \\
\hline 2 & C1-S1-2 & 21.83 & 0.060 & 58.57 & 6.339 & 40.855 & 77.056 & 2.506 & 79.563 & Export Image \\
\hline 3 & C1-S1-3 & 21.65 & 0.058 & 60.10 & 6.316 & 40.855 & 76.421 & 2.391 & 78.812 & \\
\hline 4 & C1-S1-4 & 22.31 & 0.064 & 57.74 & 6.198 & 40.855 & 78.751 & 2.837 & 81.588 & Return \\
\hline 5 & C1-56-1 & 22.64 & 0.086 & 48.02 & 5.907 & 47.324 & 92.570 & 4.772 & 97.342 & \\
\hline 6 & C1-56-2 & 22.95 & 0.081 & 49.40 & 6.210 & 47.324 & 93.837 & 4.318 & 98.155 & \\
\hline 7 & C1-56-3 & 24.93 & 0.086 & 50.41 & 6.102 & 47.324 & 101.933 & 5.010 & 106.943 & \\
\hline 8 & C1-56-4 & 22.50 & 0.076 & 51.27 & 6.247 & 47.324 & 91.997 & 3.909 & 95.906 & \\
\hline 9 & C1-58-1 & 21.77 & 0.066 & 58.53 & 6.725 & 55.269 & 103.957 & 3.888 & 107.846 & \\
\hline 10 & C1-58-2 & 22.03 & 0.057 & 57.04 & 6.686 & 55.269 & 105.199 & 2.774 & 107.972 & \\
\hline 11 & C1-58-3 & 22.89 & 0.062 & 56.81 & 6.711 & 55.269 & 109.305 & 3.304 & 112.609 & \\
\hline 12 & C1-58-4 & 22.83 & 0.059 & 58.91 & 6.666 & 55.269 & 109.019 & 3.083 & 112.102 & \\
\hline 13 & C1-S12-1 & 27.61 & 0.045 & 117.56 & 6.223 & 34.622 & 82.590 & 2.506 & 85.096 & \\
\hline 14 & C1-S12-2 & 22.76 & 0.040 & 120.81 & 6.132 & 34.622 & 68.082 & 2.001 & 70.083 & \\
\hline 15 & C1-S12-3 & 24.80 & 0.042 & 118.59 & 6.178 & 34.622 & 74.184 & 2.181 & 76.365 & \\
\hline 16 & C1-S12-4 & 20.76 & 0.038 & \begin{tabular}{|l|}
128.80 \\
\end{tabular} & 5.926 & 34.622 & 62.100 & 1.911 & 64.010 & \\
\hline 17 & C1-S16-4 & 21.77 & 0.013 & 667.56 & 4.402 & 27.557 & 51.833 & 0.544 & 52.377 & \\
\hline 18 & C1-S20-1 & 27.39 & 0.033 & 160.11 & 5.356 & 33.714 & 79.785 & 1.364 & 81.149 & \\
\hline 19 & C1-S20-2 & 24.87 & 0.038 & 158.68 & 5.395 & 33.714 & 72.444 & 1.843 & 74.288 & \\
\hline 20 & C1-520-3 & 22.06 & 0.026 & 152.33 & 5.594 & 33.714 & 64.259 & 0.989 & 65.248 & \\
\hline 21 & C1-S20-4 & 22.62 & 0.037 & 154.81 & 5.685 & 33.714 & 65.890 & 2.142 & 68.032 & \\
\hline 22 & C2-S1-1 & 21.090 & 0.051 & 51.310 & 7.544 & 26.064 & 47.4927 & 1.505 & 48.998 & \\
\hline 23 & C2-51-2 & 16.800 & 0.050 & 54.800 & 7.463 & 26.064 & 37.8320 & 1.403 & 39.236 & \\
\hline 24 & C2-51-3 & 20.450 & 0.051 & 56.830 & 7.363 & 26.064 & 46.0515 & 1.518 & 47.570 & \\
\hline 25 & C2-56-1 & 20.010 & 0.051 & 52.130 & 6.688 & 28.984 & 50.1092 & 1.466 & 51.575 & \\
\hline 26 & C2-56-2 & 19.380 & 0.056 & 55.440 & 6.454 & 28.984 & 48.5316 & 1.734 & 50.266 & \\
\hline 27 & $C 2-56-3$ & 19.370 & 0.054 & 54.360 & 6.625 & 28.984 & 48.5065 & 1.726 & 50.233 & \\
\hline 28 & C2-58-1 & 20.780 & 0.053 & 58.540 & 6.884 & 21.698 & 38.9568 & 1.554 & 40.511 & \\
\hline 29 & C2-58-2 & 20.720 & 0.053 & 56.930 & 7.230 & 21.698 & 38.8444 & 1.511 & 40.355 & \\
\hline 30 & C2-S8-3 & 24.360 & 0.060 & 57.770 & 7.107 & 21.698 & 45.6684 & 1.997 & 47.665 & \\
\hline 31 & C2-S12-1 & 28.530 & 0.042 & 113.270 & 6.792 & 21.159 & 52.1574 & 1.810 & 53.968 & \\
\hline 32 & C2-S12-2 & 26.500 & 0.038 & 118.210 & 6.500 & 21.159 & 48.4462 & 1.383 & 49.830 & \\
\hline 33 & C2-S12-3 & 28.670 & 0.040 & 112.930 & 6.745 & 21.159 & 52.4133 & 1.627 & 54.040 & \\
\hline 34 & C2-S16-1 & 40.380 & 0.022 & 616.410 & 3.151 & 32.788 & 114.3922 & 1.004 & 115.396 & \\
\hline 35 & C2-S16-2 & 35.210 & 0.024 & 625.810 & 2.993 & 32.788 & 99.7462 & 1.249 & 100.995 & \\
\hline 36 & C2-516-3 & 41.260 & 0.021 & 622.870 & 3.272 & 32.788 & 116.8852 & 0.911 & 117.796 & \\
\hline 37 & C2-S19-1 & 24.510 & 0.025 & 258.300 & 6.135 & 13.359 & 28.2895 & 0.987 & 29.276 & \\
\hline 38 & C2-S19-2 & 23.470 & 0.015 & 264.950 & 5.932 & 13.359 & 27.0892 & 0.339 & 27.428 & \\
\hline 39 & C2-S19-3 & 18.080 & 0.018 & 264.920 & 5.955 & $13.359 \quad A$ & 20.8680 & 0.500 & 21.368 & \\
\hline
\end{tabular}

Figure 3 - Total load calculation screen on NH SEDIMENT AND STATISTIC: (A) input data area for total solid discharge calculation; (B) output data area of measured and unmeasured solid discharge, and total solid discharge; (C) panel control area.

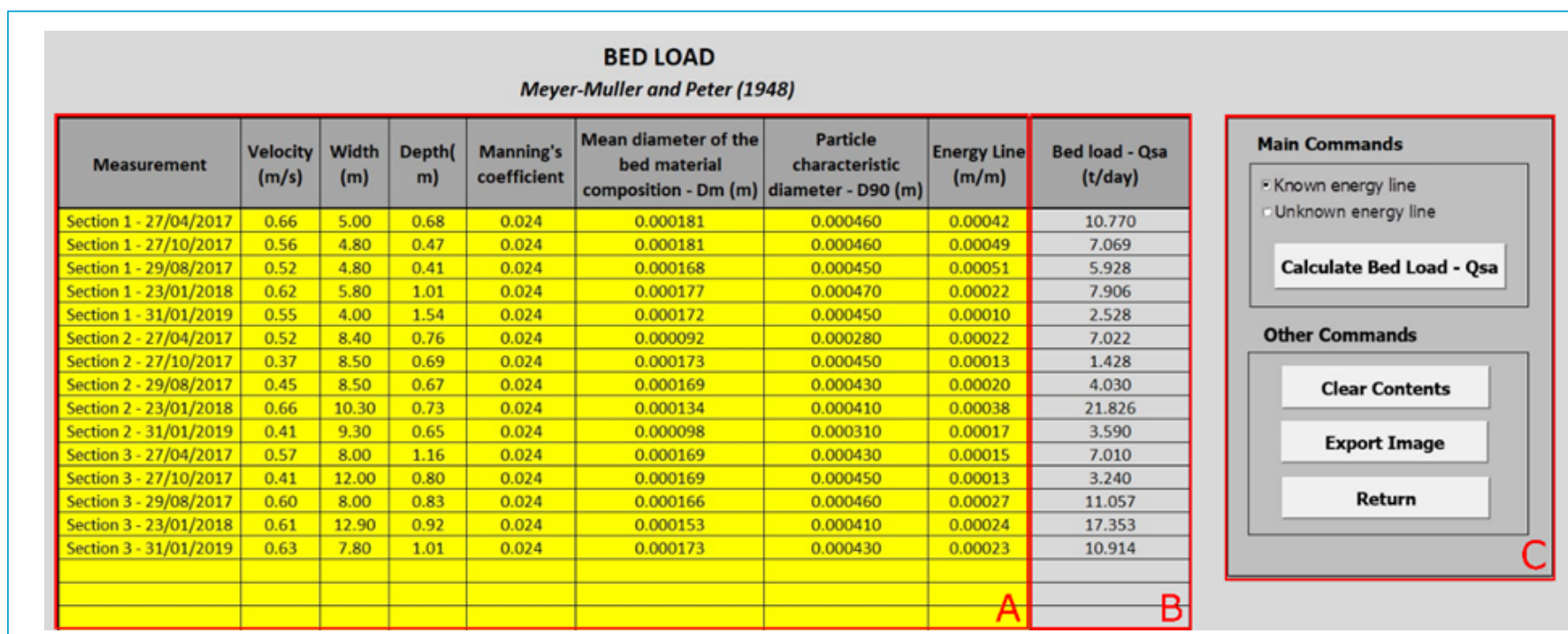

Source: elaborated by the authors.

Figure 4 - Bed load calculation screen on NH SEDIMENT AND STATISTIC: (A) input data area for bed load calculation; (B) output data area; (C) panel control area. 


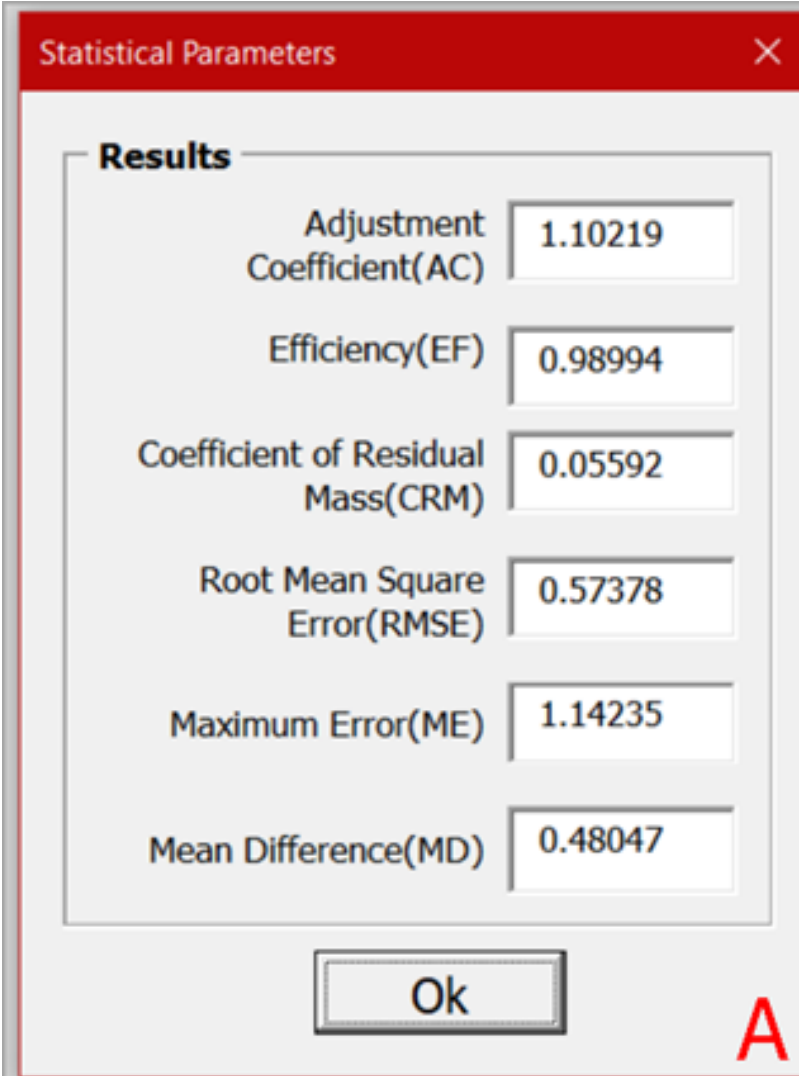

\section{- Results}

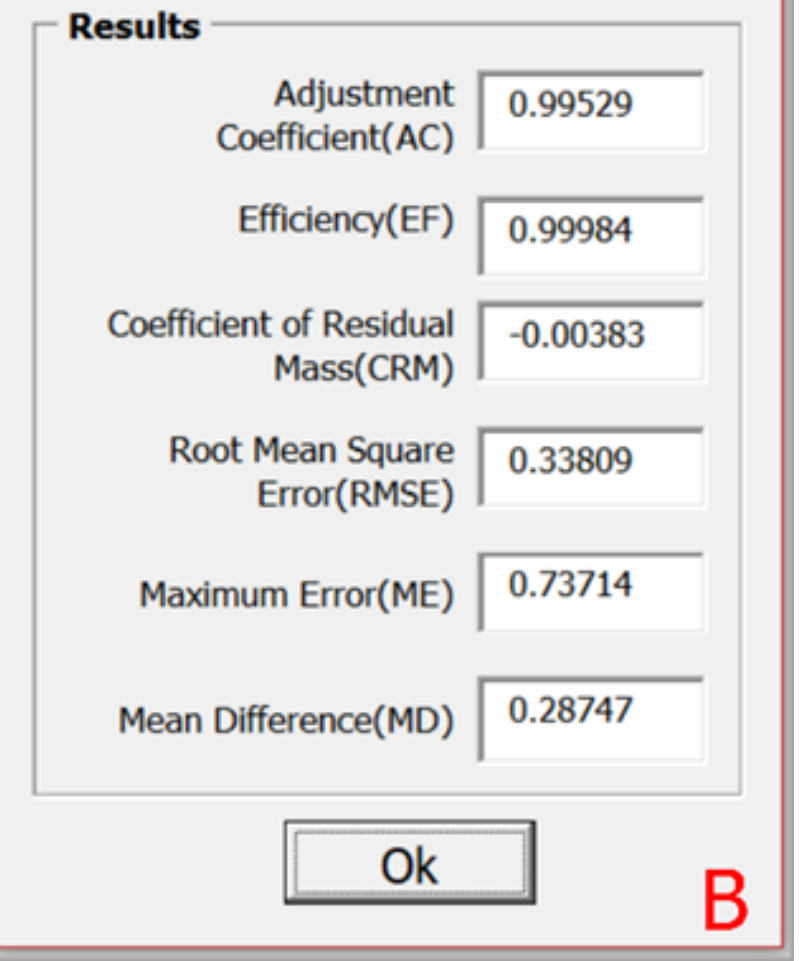

Source: elaborated by the authors.

Figure 5 - Statistical parameters: (A) bed load comparison results; (B) total load comparison results.

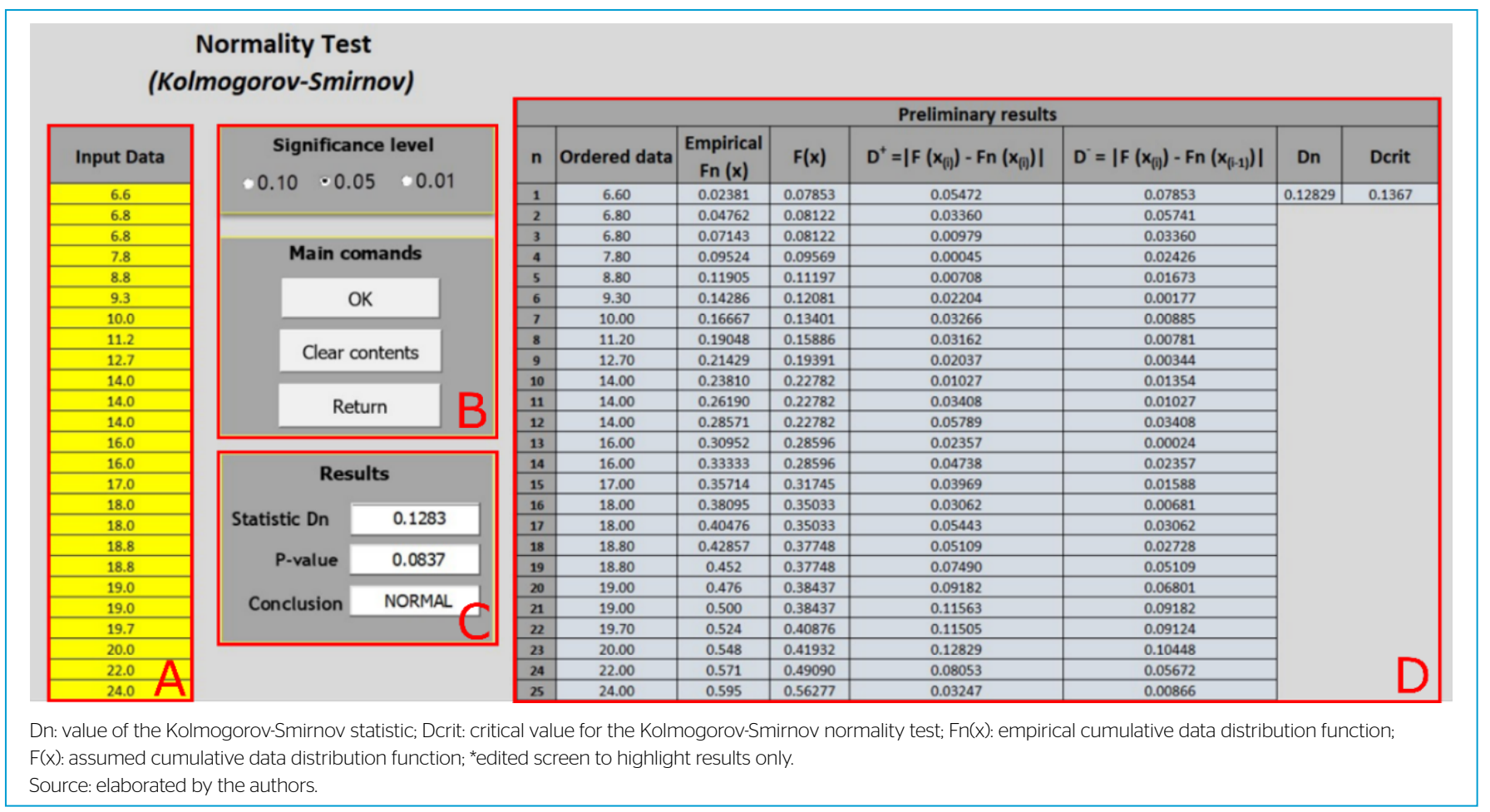

Figure 6 - Normality test applied to the SSC data showing the main results provided by the NHSS: (A) input data area; (B) panel control area; (C) output data area; (D) preliminary results area*. 


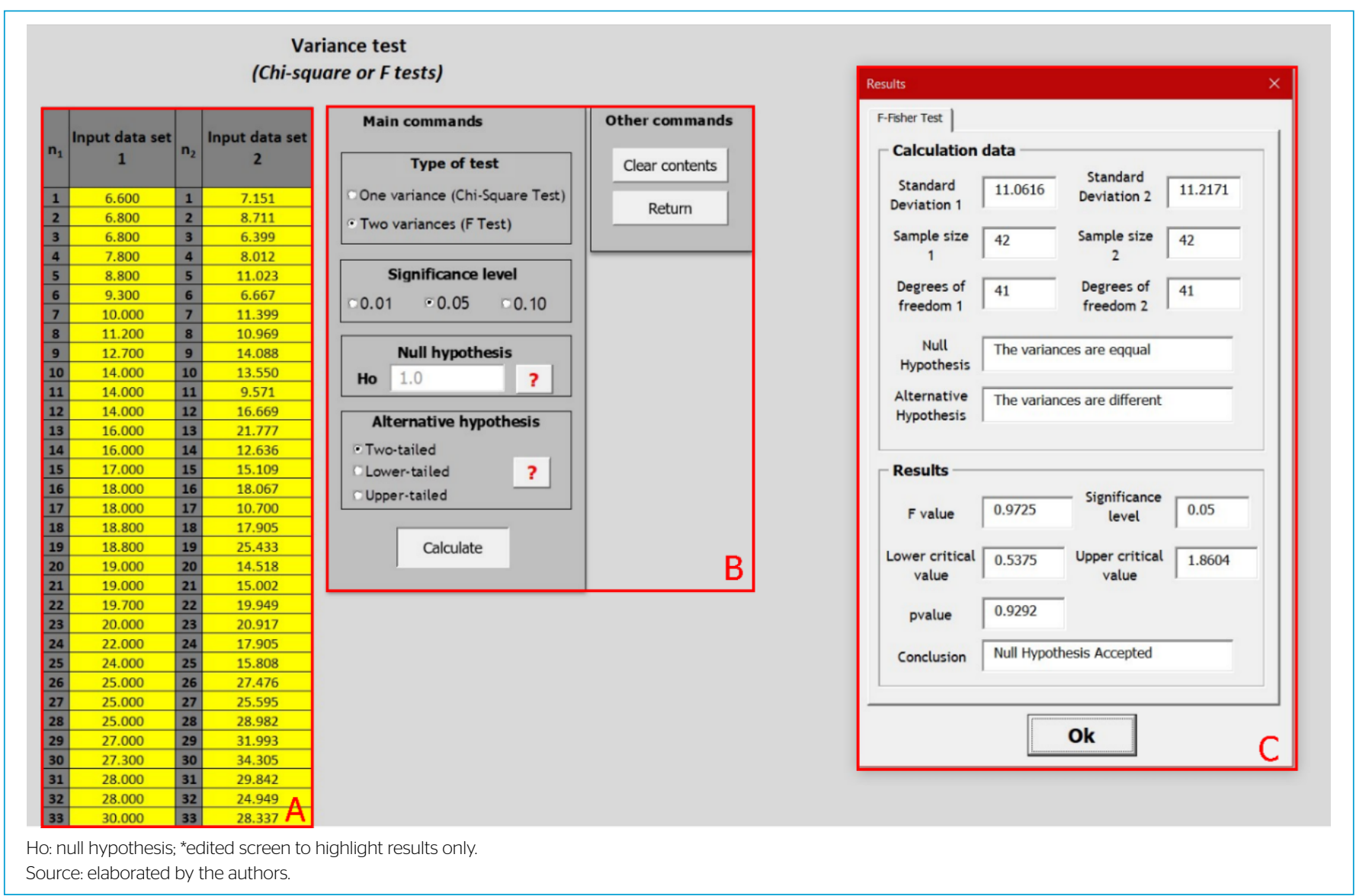

Figure 7 - F-Fisher test applied to compare measured and estimated suspended sediment concentration data showing the main results provided by the NHSS: (A) input data area; (B) panel control area; (C) output data window*.

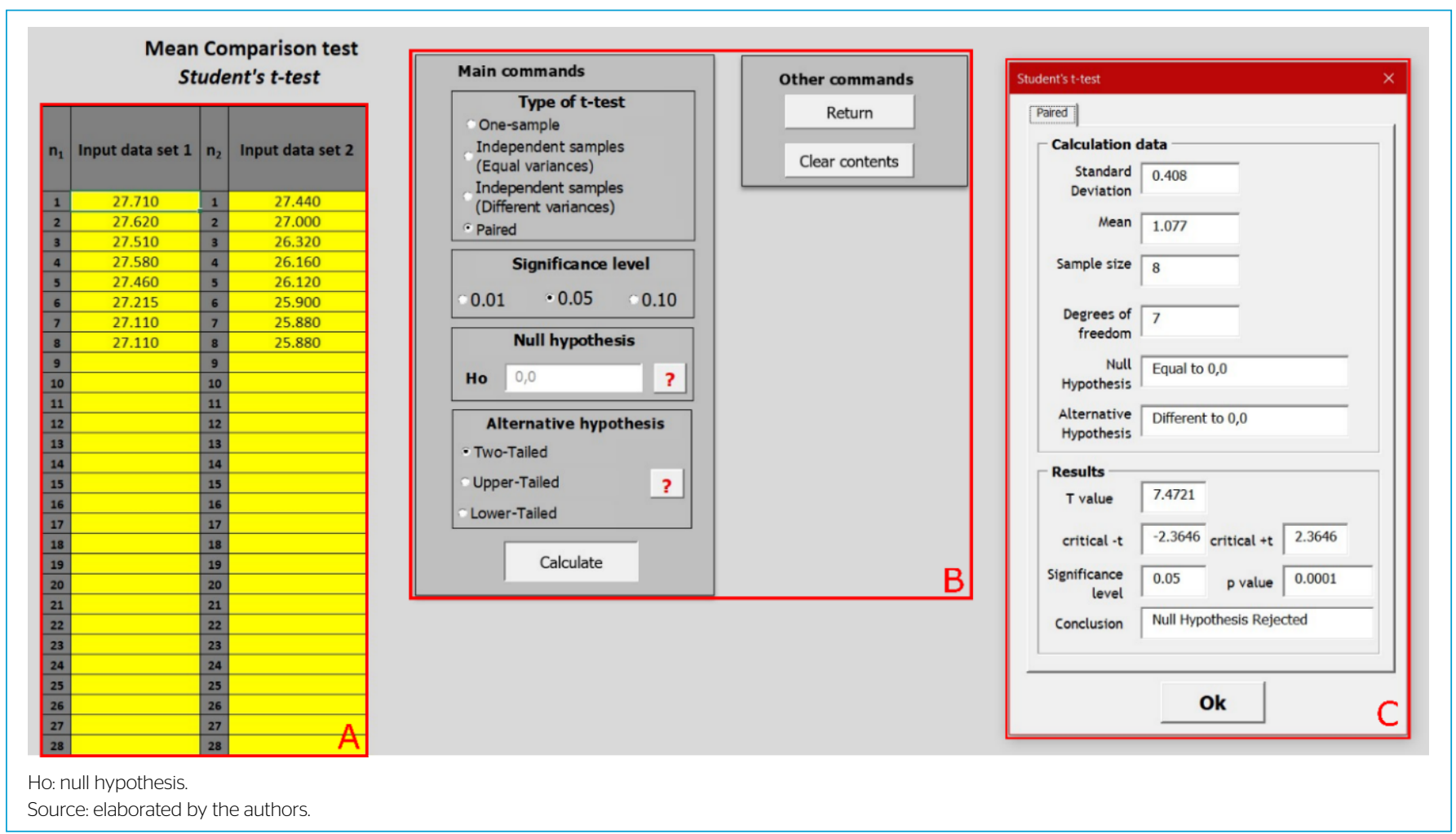

Figure 8 - Paired Student's t-test applied to compare the means of temperatures from profiles of the Mogi-Guaçu reservoir: (A) input data area; (B) panel control area; (C) output data window. 
While R is primarily a statistical tool, the NHSS allows the user to work with statistical tests and hydrosedimentological calculation methods, which is unique in this case. Finally, the developed computational tool is an open and free-to-use source and allows the user to modify the equations and enter any other statistical tests they may need.

\section{CONCLUSIONS}

Hydrosedimentology and statistics are fundamental sciences for the knowledge of processes related to sediment dynamics in water resources and are directly related to their planning and management. Due to the few options available for free and open access statistical software, which are easy to apply and focused on hydrosedimentological studies, we developed the NHSS computational tool in Visual Basic for programming language applications.
The user license is free, and the script, manuals, and guides are available online, acknowledging the implementation of other methods as needed and changes to the existing ones. The NHSS computational tool does not require prior knowledge of computational language and allows the user to work with statistical tests and methods of hydrosedimentological calculations, which is unique in this case.

Distinct modules in the tool allows the user, even with little domain in statistics, to apply their results obtained from the hydrosedimentological module directly in the statistical module. Moreover, we strive with NHSS to optimize time without needing to purchase other software to perform statistical analysis.

Finally, this article shows the applicability of the computational tool for hydrosedimentological and statistical studies, as well as the possibility of using it in any study area, contributing to the reduction of sediment-related problems in the areas of hydraulic engineering, geology, soil, and water conservation, and water resources planning.

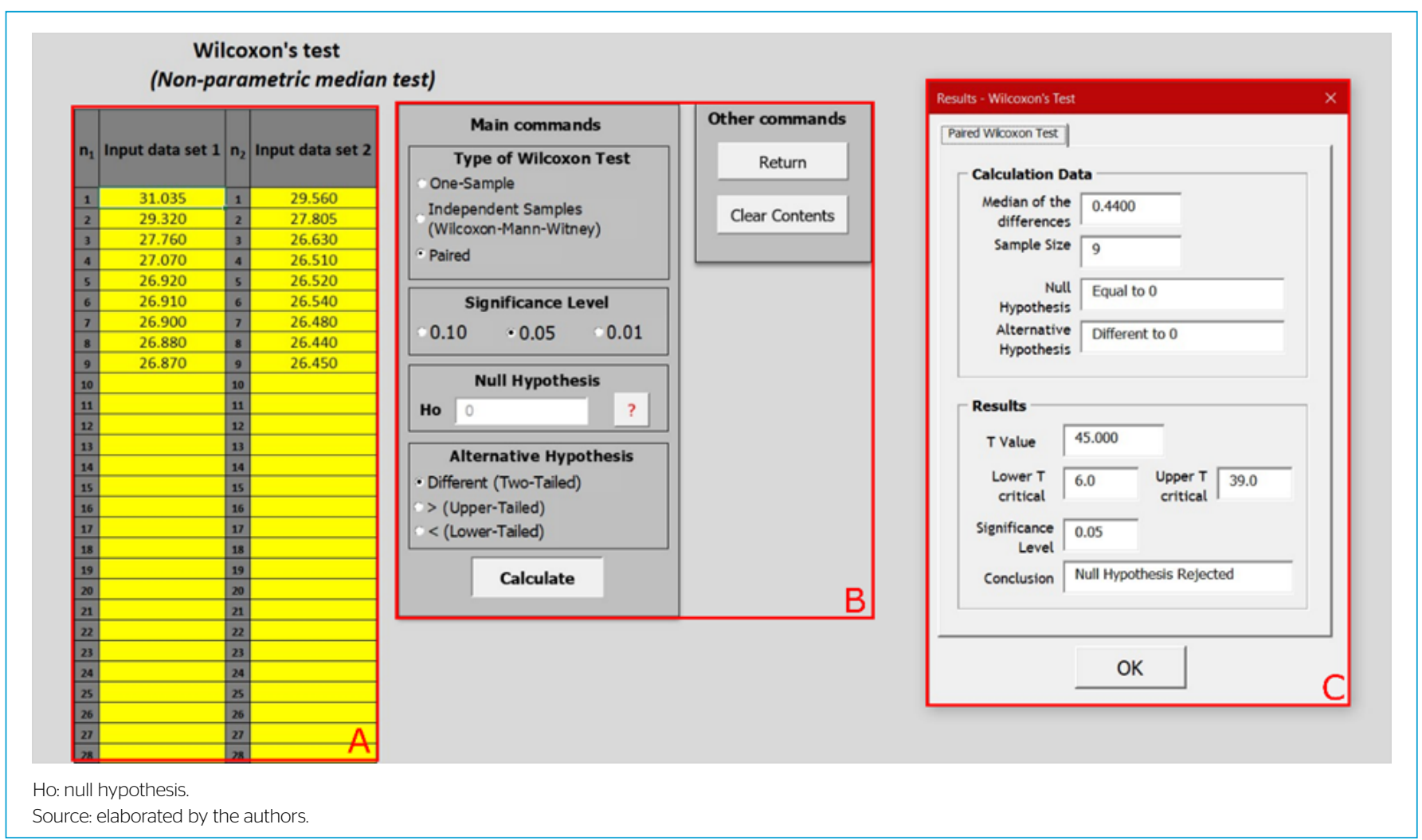

Figure 9 - Paired Wilcoxon's test applied to compare the medians of temperatures from different profiles of the Mogi-Guaçu reservoir: (A) input data area; (B) panel control area; (C) output data window.

Table 1 - Comparison of main statistical test results between NHSS and R software using statistical parameters.

\begin{tabular}{|c|c|c|c|c|c|c|c|}
\hline Test & Compared Results & $\mathrm{AC}$ & $\mathrm{EF}$ & CRM & RMSE & ME & MD \\
\hline \multirow{2}{*}{ Normality Test } & Dn & 1.00345 & 0.99996 & 0.00061 & 0.00067 & 0.00252 & 0.00037 \\
\hline & $P$ value & 1.07917 & 0.99728 & 0.00530 & 0.00494 & 0.01240 & 0.00346 \\
\hline \multirow{2}{*}{ F-Fisher test } & F value & 0.99126 & 0.99998 & -0.00107 & 0.00391 & 0.01330 & 0.00160 \\
\hline & $P$ value & 0.99664 & 0.99997 & 0.00067 & 0.00145 & 0.00380 & 0.00100 \\
\hline \multirow{2}{*}{ Student's test } & T value & 1.00039 & 0.99999 & 0.00079 & 0.00765 & 0.01870 & 0.00512 \\
\hline & $P$ value & 0.99080 & 0.99992 & -0.00350 & 0.00252 & 0.00700 & 0.00131 \\
\hline Wilcoxon's test & $\mathrm{T}+$ value & 1.00278 & 1.00000 & 0.00110 & 0.40825 & 1.00000 & 0.16667 \\
\hline
\end{tabular}

AC: adjustment coefficient; EF: efficiency; CRM: coefficient of residual mass; RMSE: root mean square error; ME: maximum error; MD: mean difference. 


\section{ACKNOWLEDGMENTS}

The authors thank the Hydrometric Group from the Center of Water Resources and Environmental Studies of Escola de Engenharia de São Carlos at Universidade de São Paulo and the Hydrology, Erosion and Sediments Group of Universidade Federal do Mato Grosso do Sul, for the institutional support.

\section{COMPUTER CODE AVAILABILITY}

NH SEDIMENT AND STATISTIC, 2020. Lastest version: 71.2019, File Size: 6MB. Recommended Hardware configuration: 64-bit(x64) processor and 4GB memory. Software requirements: Microsoft Office 2010 (or recent), 64-bit and Microsoft Visual Basic for Applications 7.1.
Other details can be found at: https://sites.google.com/view/santosbb/ nh-sediment-and-statistic

\section{AUTHORS' CONTRIBUTIONS}

Santos, B. B.: Conceptualization, Data curation, Formal Analysis, Project administration, Methodology, Software, Validation, Writing — original draft. Mauad, F. F.: Conceptualization, Funding acquisition, Investigation, Project administration, Methodology, Resources, Supervision, Visualization, Writing — review and editing. Miranda, R. B.: Methodology, Software, Validation, Writing — original draft. Alves Sobrinho, T.: Funding acquisition, Resources, Visualization, Writing - original draft. Oliveira, P. T. S.: Funding acquisition, Resources, Project administration, Writing — review and editing.

\section{REFERENCES}

ALMAGRO, A.; THOMÉ, T.C.; COLMAN, C.B.; PEREIRA, R.B.; MARCATO JUNIOR, J.; RODRIGUES, D.B.B.; OLIVEIRA, P.T.S. Improving cover and management factor (C-factor) estimation using remote sensing approaches for tropical regions. International Soil and Water Conservation Research, v. 7, n. 4, p. 325334, 2019. https://doi.org/10.1016/j.iswcr.2019.08.005

ALONSO, C.V.; NEIBLING, W.H.; FOSTER, G.R. Estimating Sediment Transport Capacity in Watershed Modeling. Transactions of the ASAE, v. 24, n. 5, p. 12111220, 1981. https://doi.org/10.13031/2013.34422

ALVES SOBRINHO, T.; VITORINO, A.C.T; SOUZA, L.C.F.; GONÇALVES, M.C:; CARVALHO, D.F. Infiltração de água no solo em sistemas de plantio direto e convencional. Revista Brasileira de Engenharia Agrícola e Ambiental, v. 7. n. 2, p. 191-196, 2003. https://doi.org/10.1590/S1415-43662003000200001

AMERICAN PUBLIC HEALTH ASSOCIATION (APHA). Standard methods for examination of water and wastewater. 19th ed. Washington, D.C.: APHA, 1995.

BEN-TAL, A.; SHAMAILOV, S.S.; PATON, J.F.R. Central regulation of heart rate and the appearance of respiratory sinus arrhythmia: New insights from mathematical modeling. Mathematical Biosciences, v. 255, p. 71-82, 2014. https://doi.org/10.1016/j.mbs.2014.06.015

BIELENKI JUNIOR, C:; SANTOS, F.M.; POVINELLI, S.C.S.; MAUAD, F.F. Alternative methodology to gap filling for generation of monthly rainfall series with GIS approach. Brazilian Journal of Water Resources, v. 23, 2018. https://doi.org/10.1590/2318-0331.231820170171

BRITO, A.S.: LIBARDI, P.L;:MOTA, J.C.A.; MORAES, S.O. Desempenho do tensiômetro com diferentes sistemas de leitura. Revista Brasileira de Ciência do Solo, v. 33, n. 1, p. 17-24, 2009. https://doi.org/10.1590/S0100-06832009000100002

CAMPEÃO, R.A.C.; HORA, M.A.G. Avaliação do transporte de sedimentos: SEDIM 2.O. In: COTIAN, L.F.P. (org.). Engenharias, ciência e tecnologia 2. Ponta Grossa: Atena, 2019. v. 2. p. 30-37.

CARVALHO, N.O. Hidrossedimentologia prática. 2. ed. Rio de Janeiro: Interciência, 2008
COLBY, B.R. Relationship of unmeasured sediment discharge to mean velocity. Transactions, American Geophysical Union, v. 38, n. 5, p. 708-717, 1957. https://doi.org/10.1029/TR038i005p00708

COLMAN, C.B.; GARCIA, K.M.P.; PEREIRA, R.B.; SHINMA, E.A.; LIMA, F.E. GOMES, A.O.; OLIVEIRA, P.T.S. Different approaches to estimate the sediment yield in a tropical watershed. Brazilian Journal of Water Resources, v. 23, e47, 2018. https://doi.org/10.1590/2318-0331.231820170178

CONOVER, W.J. Practical nonparametric statistics. 3. ed. New York: John Wiley \& Sons, 1999.

DALLAL, G.E.; WILKINSON, L. An Analytic Approximation to the Distribution of Lilliefors's Test Statistic for Normality. The American Statistician, v. 40, n. 4, p. 294-296, 1986. https://doi.org/10.1080/000313 05.1986 .10475419

DOUZIECH, M.; CONESA, I.R.; BENITEZ-LÓPEZ, A.; FRANCO, A.; HUIJBREGTS, M.; VAN ZELM, R. Quantifying variability in removal efficiencies of chemicals in activated sludge wastewater treatment plants - a meta-analytical approach. Environmental Science: Processes \& Impacts, v. 20, n. 1, p. 171-182, 2018. https://doi.org/10.1039/C7EM00493A

ENVIRONMENTAL COMPANY OF THE STATE OF SÃO PAULO (CETESB). Internal water quality report of the state of São Paulo: appendix B. São Paulo: CETESB, 2017. Available at: https://cetesb.sp.gov.br/aguas-interiores/ publicacoes-e-relatorios/. Accessed on: Aug 20, 2019

ESTIGONI, M.V.; MIRANDA, R.B.; MAUAD, F.F. Hydropower reservoir sediment and water quality assessment. Management of Environmental Quality, v. 28, n. 1, p. 43-56, 2017. https://doi.org/10.1108/MEQ-07-2015-0153

FOUNDATION FOR RESEARCH INCREASE AND INDUSTRIAL IMPROVEMENT (FIPAI). Desenvolvimento, validação e aplicação de um modelo tridimensional de transporte de sedimentos em reservatório aplicado ao cálculo e elaboração de projeções futuras de geração hidrelétrica (Relatório Final No. ANEEL PD-0064-1028/2011). São Carlos: FIPAI, 2015 
GARTNER, J.W. Estimating suspended solids concentrations from backscatter intensity measured by acoustic Doppler current profiler in San Francisco Bay, California. Marine Geology, v. 211, n. 3-4, p. 169-187, Oct. 2004. https://doi.org/10.1016/j.margeo.2004.07.001

GRAY, J.R.; LANDERS, M.N. Measuring Suspended Sediment. In: U.S. GEOLOGICAL SURVEY (org.). Comprehensive Water Quality and Purification. Elsevier, 2014. v. 1. p. 157-204. https://doi.org/10.1016/B978-0-12382182-9.00012-8

GRAY, J.R.; SIMÕES, F.J.M. Estimating Sediment Discharge. In: GARCIA, M. (org.). Sedimentation Engineering: Processes, Measurements, Modeling, and Practice. Reston: American Society of Civil Engineers, 2008. p. 10671088. https://doi.org/10.1061/9780784408148

LENGNICK, L.L.; FOX, R.H. Simulation by NCSWAP of Seasonal Nitrogen Dynamics in Corn: I. Soil Nitrate. Agronomy Journal, v. 86, n. 1, p. 167-175, 1994. https://doi.org/10.2134/agronj1994.00021962008600010030x

LILLIEFORS, H.W. On the Kolmogorov-Smirnov Test for Normality with Mean and Variance Unknown. Journal of the American Statistical Association, v. 62, n. 318, p. 399-402, 1967. https://doi.org/10.1080/01621459.1967.10482916

MANN, H.B.; WHITNEY, D.R. On a Test of Whether one of Two Random Variables is Stochastically Larger than the Other. The Annals of Mathematical Statistics, v. 18, n. 1, p. 50-60, 1947. https://doi.org/10.1214/amos/1177730491

MARQUES, V.; CEDDIA, M.; ANTUNES, M.; CARVALHO, D.; ANACHE, J.; RODRIGUES, D.; OLIVEIRA, P. USLE K-Factor Method Selection for a Tropical Catchment. Sustainability, v. 11, n. 7. p. 1840, 2019. https://doi.org/10.3390/ su11071840

MEYER-PETER, E.; MULLER, R. Formulas for bed load transport. In: INTERNATIONAL ASSOCIATION FOR HYDRAULIC STRUCTURES RESEARCH, Stockholm. Annals [...]. 1948. p. 39-64.

MITCHELL, M. Software Engauge Digitizer. Available at https:// markummitchell.github.io/engauge-digitizer/ Accessed on: Sep. 23, 2019. https://doi.org/10.5281/zenodo.3370364

MOGI GUAÇU RIVER BASIN COMMITTEE (CBH MOGI). Water Resources Status Report 2018 (base year 2017). São Paulo: CBH Mogi, 2018.

NAGY, H.M.; WATANABE, K.; HIRANO, M. Prediction of Sediment Load Concentration in Rivers using Artificial Neural Network Model. Journal of Hydraulic Engineering, v. 128, n. 6, p. 588-595, June 2002. https://doi. org/10.1061/(ASCE)0733-9429(2002)128:6(588)

NATIONAL WATER AGENCY (ANA). Orientações para operações das estações hidrométricas. Brasília: ANA, SGH, 2012.

OCAYA, R.O. A current-voltage-temperature method for fast extraction of schottky diode static parameters. Measurement, v. 49, p. 246-255, Mar. 2014. https://doi.org/10.1016/j.measurement.2013.11.059

OEURNG, C.; SAUVAGE, S.; SÁNCHEZ-PÉREZ, J.-M. Dynamics of suspended sediment transport and yield in a large agricultural catchment, southwest France. Earth Surface Processes and Landforms, v. 35, n. 11, p. 1289-1301, 2010. https://doi.org/10.1002/esp.1971
ROSA, L.H.; BELING, F.A. Software WinTSR: Controle de Sedimentos em Rios. Santa Maria: UFSM, 2002

SANTOS, B.B.; ALVES SOBRINHO, T.; SOUZA, J.S.; CARVALHO, G.A.; POMPEU, R.M.; COUTO, C.B. Avaliação de métodos de estimativas de descarga sólida de leito em rios. In: POLETO, C. (org.). X Encontro Nacional de Engenharia de Sedimentos: artigos selecionados. Porto Alegre: ABRH, 2012. p. 345-355.

SANTOS, B.B.; MIRANDA, R.B.; ESTIGONI, M.V.; VILLELA, J.M.; MAUAD F.F. Evaluation of the laser diffraction method for the measurement of suspended sediment concentration in Mogi-Guaçu reservoir (São Paulo, Brazil). International Journal of River Basin Management, v. 17, n. 1, p. 89-99, 2019. https://doi.org/10.1080/15715124.2018.1446965

SCAPIN, J.; PAIVA, J.B.D.D.; BELING, F.A. Avaliação de Métodos de Cálculo do Transporte de Sedimentos em um Pequeno Rio Urbano. Revista Brasileira de Recursos Hidricos, v. 12, n. 4, p. 5-21, 2007. https://doi.org/10.21168/rbrh. v12n4.p5-21

SENTELHAS, P.C:; MORAES, S.O.; PIEDADE, S.M.S.; PEREIRA, A.R.; ANGELOCCI, L.R.; MARIN, F.R. Comparative Analysis of meteorological data obtained by conventional and automatic weather stations. Revista Brasileira de Agrometeorologia, v. 5, n. 2, p. 215-221, 1997.

SONE, J.S.; GESUALDO, G.C.; ZAMBONI, P.A.P.; VIEIRA, N.O.M.; MATTOS, T.S. CARVALHO, G.A.; RODRIGUES, D.B.B.; ALVES SOBRINHO, T.; OLIVEIRA, P.T.S. Water provisioning improvement through payment for ecosystem services. Science of The Total Environment, v. 655, p. 1197-1206, 2019. https:/l doi.org/10.1016/j.scitotenv.2018.11.319

STEPHENS, M.A. EDF Statistics for Goodness of Fit and Some Comparisons. Journal of the American Statistical Association, v. 69, n. 347, p. 730-737, 1974 https://doi.org/10.1080/01621459.1974.10480196

STEVENS, H.H.; YANG, C.T. Summary and use of selected fluvial sedimentdischarge formulas. Denver: U.S. Geological Survey, 1989. Available at: https://pubs.er.usgs.gov/publication/wri894026. Accessed on: Sep. 21, 2019 https://doi.org/10.3133/wri894026

SUN, L.; YAN, M.; CAI, Q.; FANG, H. Suspended sediment dynamics at different time scales in the Loushui River, south-central China. CATENA, v. 136, p. 152-161, 2016. https://doi.org/10.1016/j.catena.2015.02.014

THE R FOUNDATION. The $R$ Project for Statistical Computing. The R Foundation. Available at: https://www.r-project.org/. Accessed on: Sep. 15, 2019

VERCRUYSSE, K.; GRABOWSKI, R.C.; RICKSON, R.J. Suspended sediment transport dynamics in rivers: Multi-scale drivers of temporal variation. Earth-Science Reviews, v. 166, p. 38-52, 2017. https://doi.org/10.1016/j. earscirev.2016.12.016

WILCOXON, F. Individual Comparisons by Ranking Methods. Biometrics Bulletin, v. 1, n. 6, p. 80-83, Dec. 1945. https://doi.org/10.2307/3001968

XAVIER, B.C.; SILVA, I.O.; GUIMARÃES, L.G.; GALLO, M.N.; RIBEIRO, C.P.; JUNIOR FIGUEIREDO, A.G. Estimation of suspended sediment concentration by acoustic scattering: an experimental and theoretical analysis for spherical particles. Journal of Soils and Sediments, v. 14, n. 7. p. 1325-1333, 2014. https:// doi.org/10.1007/s11368-014-0905-5 